\title{
Gambaran Kadar Hemoglobin pada Sediaan Produk Darah Packed Red Cells (PRC) selama Masa Simpan 20 hari
}

Wiwit Sepvianti*, Meyta Wulandari, Serafica Btari Christiyani Kusumaningrum, Sunartono Sunartono dan Taib Djafar

\section{Intisari}

Packed Red cells (PRC) merupakan sediaan produk darah yang tercacat paling banyak digunakan pada transfusi darah. Indikasi penggunaan PRC adalah untuk menaikan kadar hemoglobin pada pasein. 1 unit PRC dapat menaikkan kadar hematokrit 3-5\%. Peran vital pemberian PRC dalam menaikkan kadar hemoglobin tidak terlepas dari fakta bahwa PRC terus mengalami penurunan kualitas selama masa penyimpanan. Hal ini disebabkan sel-sel darah mengalami lisis, sehingga berpengaruh secara langsung pada morfologi sel, kadar hemoglobin, $\mathrm{pH}$ darah, dan kadar ion-ion darah. Pada penelitian ini dilakukan pengamatan kadar Hemoglobin pada sediaan PRC selama masa simpan 20 hari menggunakan metode Rapid test. Sampel penelitian sejumlah 3 kantong darah PRC bergolongan darah O rhesus positif. Hasil pengamatan kadar Hemoglobin pada sampel PRC menunjukkan terjadi penurunan kadar PRC pada masa simpan 20 hari yang berkisar antara 7,8-11,2\%.

Kata kunci: Packed red cells, PRC, Hemoglobin dan masa simpan

\section{Pendahuluan}

Transfusi darah merupakan salah satu perawatan kesehatan yang vital dewasa ini, perawatan kesehatan tersebut merupakan kegiatan pemindahan darah donor kepada pasien. Upaya transfusi darah secara medis dilakukan pada beberapa kondisi seperti anemia kronik, kelainan darah (Thalasemia, Hemofilia, Leukimia, gagal ginjal kronik serta perdarahan masif (trauma, proses pembedahan, DIC, perdarahan GI dan juga pada proses persalinan) ${ }^{1}$. Pada kondisi medis tersebut tubuh pasien tidak bisa memproduksikan darah dengan baik, sehingga secara langsung mempengaruhi berbagai sistem dalam tubuh².

\section{Afiliasi Penulis \\ Prodi D3 Teknologi Transfusi Darah STIKes Guna Bangsa Yogyakarta}

\section{Korespondensi kepada}

W. Sepvianti

wiwit.sepvianti01@gmail.com
Terdapat beberapa jenis produk darah yang diproduksi, meliputi darah lengkap (whole blood), sel darah merah pekat (packed red cells), konsentrat trombosit (thrombocyte concentrate) dan plasma darah ${ }^{3}$. Setiap jenis produk darah yang digunakan merujuk pada indikasi medis pasien ${ }^{4}$, seperti pada kondisi medis perdarahan (syok hipovolemik) dengan kehilangan cairan tubuh lebih dari 30\%, anemia kronik dan pembedahan mayor dengan perdarahan lebih dari $1500 \mathrm{~mL}$ membutuhkan tranfusi dalam sediaan darah lengkap sedangkan pada pasien yang mengalami penurunan kadar $\mathrm{Hb}$ akan ditransfusikan produk sel darah merah pekat dan pasien dengan kondisi medis trombositopenia akan mendapatkan transfusi dengan produk darah thrombocyte concentrate $^{5}$. Perbedaan nyata antara darah dan sediaan farmasi lainnya adalah sediaan darah memiliki rentang kadaluarsa yang pendek dan semakin bertambahnya usia penyimpanan menyebabkan penurunan kualitas darah yang diakibatkan sel-sel darah mengalami lisis ${ }^{6}$. Walaupun begitu penggunaan darah untuk 
transfusi tidak dapat disubtitusi dengan barang/ produk lainnya. Pada penelitian ini, dilakukan observasi kadar hemoglobin pada sediaan PRC sebagai salah satu parameter kualitas PRC.

\section{Metode}

Penelitian ini merupakan penelitian observasional deskriptif dengan rancangan cross sectional. Penelitian dilakukan di PMI Kabupaten Sleman. Sampel penelitian adalah tiga kantong darah PRC dengan anti koagulan CPDA-1 dan bergolongan darah $\mathrm{O}$ Rhesus Positif yang berasal dari tiga donor. Pengukuran kadar Hemoglobin pada sediaan darah PRC menggunakan metode Rapid-test.

Alat

Alat yang dibutuhkan pada penelitian ini yaitu hemoglobinometer, klem, gunting, pinset anatomi dan hand sealer.

\section{Bahan}

Bahan yang digunakan pada penelitian ini yaitu 3 kantong darah PRC dan strip tes $\mathrm{Hb}$ meter.

\section{Prosedur penelitian}

\section{Pembuatan sediaan darah PRC}

Setiap pembuatan satu unit PRC diperlukan satu unit darah lengkap (Whole Blood). Prinsip pembentukan PRC adalah memisahkan sel darah merah dengan plasma. Salah satu metode pemisahan yang dapat dilakukan adalah sentrifugasi. Sediaan WB diputar pada sentrifuse dengan kecepatan 3500 rpm selama 13 menit pada suhu $4{ }^{\circ} \mathrm{C}$. Pembuatan satu unit PRC dari $500 \mathrm{~mL}$ darah lengkap didapatkan volume sel darah merah 200-250 mL.

Pengukuran Kadar Hemoglobin

Sampel darah dihomogenkan dengan handsealer 2-3 kali, kemudian selang pada kantong dipotong untuk mengeluarkan sampel darah. Sampel darah dimasukkan dalam strip $\mathrm{Hb}$, lalu dimasukkan dalam hemoglobinometer. Kadar hemoglobin darah yang muncul pada layar hemoglobinometer dicatat.

\section{Hasil dan Pembahasan}

Pada penelitian ini digunakan 3 kantong sediaan PRC yang diproduksi dari 3 kantong WB yang berbeda. Terdapat perbedaan kadar hemoglobin yang cukup signifikan pada darah WB dan PRC. Semula 3 kantong WB memiliki kadar hemoglobin berturut-turut sebesar 13,5; 15,2 dan $16 \mathrm{~g} / \mathrm{dL}$, setelah menjadi sediaan PRC kadar hemoglobin meningkat menjadi 21,0; 21,7 dan $20,5 \mathrm{~g} / \mathrm{dL}$. Peningkatan kadar Hemoglobin merupakan hal yang lazim terjadi apabila WB diproduksi menjadi PRC. Hal ini karena prinsip produksi PRC dari WB

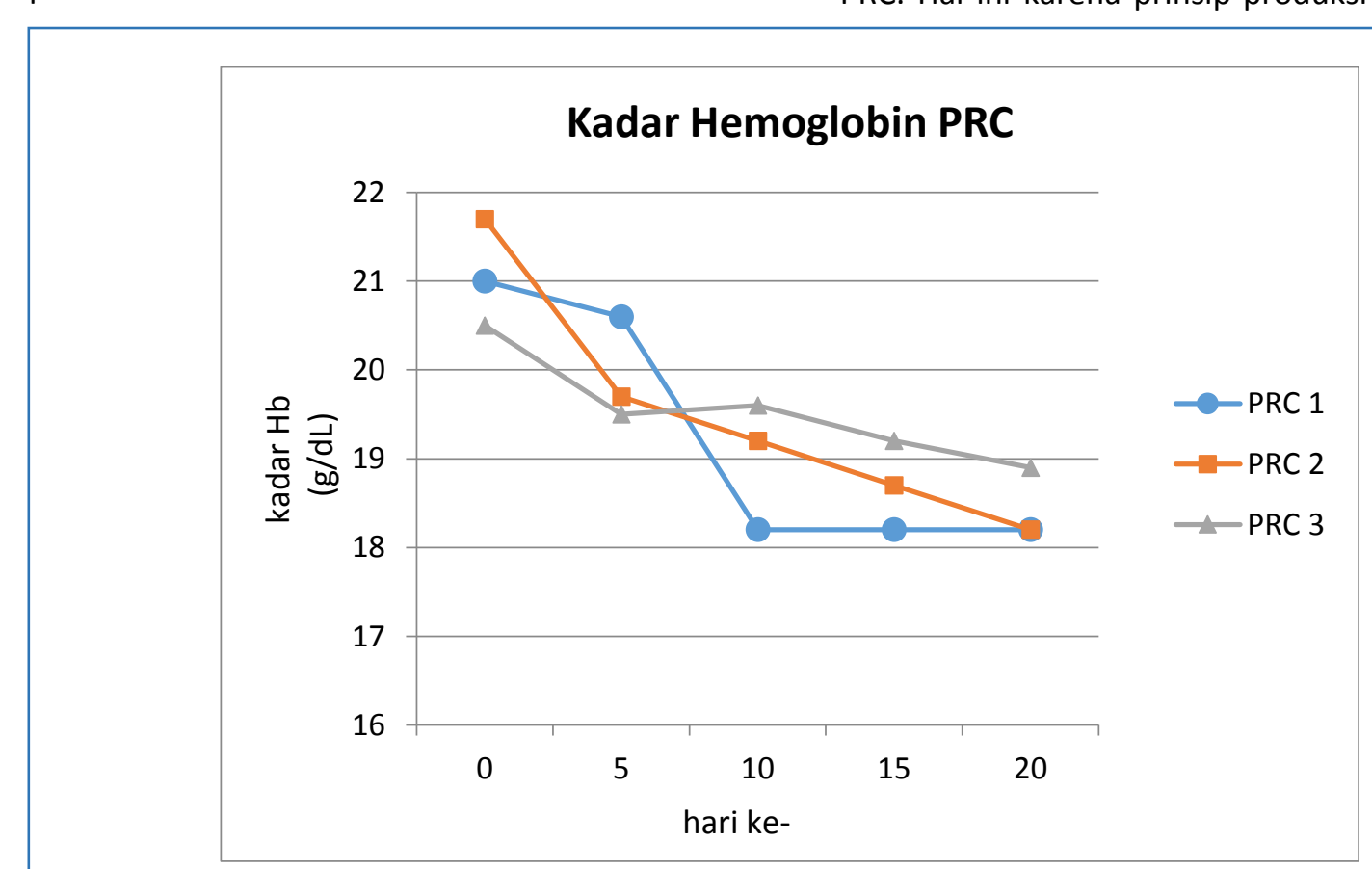

Gambar 1 | Kadar Hemoglobin pada PRC berdasarkan Masa Penyimpanan 
adalah menghilangkan plasma dan sel darah lainnya yang terdapat pada plasma yaitu sel darah putih (leukosit) dan keping darah (trombosit). Sehingga PRC merupakan sediaan sel darah merah pekat, yang menyebabkan peningkatan kadar $\mathrm{Hb}$ pada sediaan darah, mengingat kadar hemoglobin dinyatakan dalam satuan massa per volume yang merujuk pada densitas atau kerapatan suatu zat (dalam hal ini sel darah).

Pengukuran kadar Hemoglobin pada sediaan PRC dilakukan setiap 5 hari sekali selama masa simpan 20 hari. Metode yang digunakan adalah rapid test dengan alat hemoglobinometer. Adapun hasil pengamatan kadar hemoglobin pada PRC disajikan pada Gambar 1.

Pada penelitian ini diperoleh kadar Hemoglobin sediaan PRC terus mengalami penurunan selama masa simpan (Gambar 1). Hal ini terjadi diduga akibat PRC mengalami kerusakan sel darah merah/ hemolisis. Penelitian lain juga membuktikan bahwa masa simpan menyebabkan terjadinya perubahan viskositas eritrosit dan meningkatkannya stress cell induced hemolysis sehingga menyebabkan kematian pada sel eritrosit ${ }^{6}$. Kerusakan eritrosit inilah yang berdampak secara nyata pada penurunan kadar Hemoglobin dalam darah. Kerusakan ini juga dimungkinkan dapat terjadi pada komponen darah lainnya.

Pada Gambar 1. dapat dilihat bahwa PRC 2 dan 3 mengalami penurunan kadar Hemoglobin yang jauh lebih signifikan dibandingkan PRC 1. Hal ini diduga karena darah PRC 2 dan 3 yang berasal dari darah donor berkelamin laki-laki memiliki kecenderungan mengalami peningkatan suseptibilitas terhadap stress cell induced hemolysis selama penyimpanan sedangkan PRC 1 yang bersumber dari pendonor perempuan memperlihatkan kestabilan kadar Hemoglobin di hari kelima yaitu sebesar $0,4 \mathrm{~g} / \mathrm{dL}$ dan pada hari kesepuluh hingga kedua puluh menunjukkan kestabilan kadar hemoglobin dengan tidak terjadinya penurunan kembali. Hal ini diduga karena darah dari donor wanita cenderung mengalami kematian sel post transfusi, bukan saat penyimpanan ${ }^{6}$.

\section{Kesimpulan}

Berdasarkan hasil penelitian yang telah dilakukan, maka dapat disimpulkan bahwa kadar hemoglobin pada sediaan darah PRC mengalami penurunan hingga 7,8-11,5\% pada 20 hari masa simpan.

\section{Bibliografi}

1. Booth C., and Allard, S., 2017, Blood Transfusion, Medicine, 46, 244-250.

2. Sutandyo, N, 2007, Transfusi pada Pasien Kanker: manfaat dan resiko, Indonesia Journal of Cancer, 3 : 115-120.

3. Kementerian Kesehatan, 2012, Permenkes RI No 91 tentang Standar Pelayanan Transfusi Darah, DKI Jakarta.

4. Darmawan, A., Irawan, $R, 2015$, Mengenal CPOB untuk Produk Darah, JMJ, 3:111-118.

5. Komisi Transfusi. 2015. Transfusi Darah. RS Saiful Anwar. Fakultas Kedokteran Universitas Brawijaya.

6. Isti, R., Rofinda, Z.D., Husni. 2018. Gambaran Morfologi Eritrosit Packed Red Cell berdasarkan Waktu Penyimpanan Di Bank Darah RSUP Dr. M Djamil Padang. Jurnal Kesehatan Andalas. 